\title{
Response of 'Reliance' Table Grapes to Canopy Management and Ethephon Application
}

\author{
John Fitzgerald ${ }^{1}$ and W. Keith Patterson ${ }^{2}$ \\ Department of Horticulture and Forestry, University of Arkansas, Fayetteville, AR 72701 \\ Additional index words. Vitis, berry color, juice color, berry chemistry, cluster thinning, leaf removal
}

\begin{abstract}
Canopy management and ethephon application (100 mg-liter ${ }^{-1} 2$ weeks after veraison) were investigated for 2 years as possible ways to improve color and overall quality of 'Reliance' grapes (Vitis spp.). Canopy management consisted of leaf removal, shoot positioning, and cluster thinning. Grapevines were subjected to one of two levels of leaf removal and one of two levels of preharvest ethephon spray and were either thinned to a basal cluster or nonthinned. Thinning and ethephon advanced harvest dates by 5 to 8 days and 2 to 3 days, respectively. In 1989, berry weight was increased by thinning but was not affected by leaf removal or ethephon. Leaf removal (direct sun exposure) of thinned and nonthinned treatments increased " $L$ " values (lighter colored fruit) in 1989. In 1990, leaf removal, ethephon, and thinning resulted in higher " $L$ " values. The "a" values were significantly increased by leaf removal in 1989 and 1990 and by thinning in 1989 , a result indicating increased skin redness. Exposed clusters of nonthinned treatments had significantly higher " $b$ " values due to more yellow fruit in 1989 than in 1990. Ethephon increased " $b$ " values in thinned and nonthinned treatments. In 1990, leaf removal increased " $b$ " values. Thinning resulted in more evenly colored, redder fruit. Leaf removal caused a lightening and yellowing of the skin. Juice from leaf removal treatments in 1990 had significantly higher " $L$ ", " $a$ ", and "b" values. Ethephon significantly increased the "a" value of juice in 1989, and leaf removal significantly increased the " $b$ " value in 1989. The percent soluble solids of juice was generally decreased by ethephon and increased by leaf removal and thinning. Titratable acidity was decreased by leaf removal and ethephon and increased by thinning in both years. Leaf removal decreased berry $\mathrm{pH}$ in 1990. Thinning increased coloration, and direct exposure to light decreased coloration. The results with ethephon were not conclusive. Chemical name used: 2-chloro-ethyl-phosphonic acid (ethephon).
\end{abstract}

Flavor, seedlessness, appearance, and size were rated as important table grape characteristics by Ohio consumers (Degner and Fairchild, 1987). 'Reliance', developed by the Univ. of Arkansas Experiment Station, is a red seedless cultivar with very high soluble solids and a delicate labrusca aroma and flavor. This cultivar has a sweet and pleasing taste that is rated outstanding (Moore, 1983) and may have potential as a juice grape by itself or for blending. In some years, however, ripened 'Reliance' clusters may have mixed red and green fruit, adversely affecting consumer appeal.

Two possible ways to improve grape coloration are canopy management to alter light and temperature and ethephon (an ethylene releasing compound) (Jensen et al., 1980; Smart, 1985; Wicks et al., 1982). Canopy management, an increasingly important component of table grape production, may include removing leaves from the vine, pruning at specific levels, shoot positioning, and cluster thinning. Canopy management can change the vine microclimate within the leaf canopy and reduce overcropping (Smart, 1985). English et al. (1990) found that removing basal leaves slightly changed temperature, atmospheric humidity, wind speed, and leaf wetness around grape clusters. Several studies reported that defoliation reduced berry weight (Buttrose, 1966; Kliewer, 1970; Kliewer and Antliff, 1970). However, other researchers reported no effect, especially when only basal leaves were removed. Yield, cluster number, cluster weight, and berry weight were not significantly affected by the timing or level of basal leaf removal; however, there were decreases in $\mathrm{pH}$ and titratable acidity (TA) and an increase in percent soluble solids (Kliewer and Bledsoe, 1987). Removing leaves from the basal

Received for publication 16 Feb. 1993. Accepted for publication 11 Feb. 1994. Published with approval of the director of the Arkansas Agricultural Experiment Station. The cost of publishing this paper was defrayed in part by the payment of page charges. Under postal regulations, this paper therefore must be hereby marked advertisement solely to indicate this fact.

${ }^{1}$ Research assistant.

${ }^{2}$ Assistant professor third of all shoots on 'Thompson Seedless' vines had relatively little effect on berry weight and percent soluble solids (May et al., 1969).

'Tokay' vines, pruned and thinned to 18 clusters, had fruit with greater coloration and percent soluble solids than unpruned and unthinned vines (Kliewer and Weaver, 1971). Flower cluster thinning on 'Mars' and 'Venus' advanced maturity and resulted in more even ripening and increased marketable yields (Clark et al., 1989).

High temperatures decreased anthocyanin content (Buttrose et al., 1971; Kliewer and Torres, 1972), reduced berry weight (Radler, 1965), and decreased sugar concentration and berry growth (Coombe, 1987). Berries exposed to direct sunlight were 2.2C warmer than nonexposed berries and their weights were lower (Kliewer and Lider, 1970). Unlike black grapes, light-colored varieties had reduced berry color in the absence of light (Wicks et al., 1982). Shading within a canopy reduces anthocyanin levels and percent soluble solids (Koblet, 1987; Morrison and Noble, 1990; Rojas-Lara and Morrison, 1989; Smart, 1982; Smart et al., 1988). Smart and Sinclair (1976), however, suggested that berries directly exposed to light had increased solar heating, which is correlated with reduced anthocyanin content.

Many studies show that ethephon improves coloration in several grape cultivars (Chakrawar and Rane, 1977; Clore and Fay, 1970; Weaver and Pool, 1971) and advances maturity (El-Banna and Weaver, 1979; Jensen et al., 1980). Depending on the cultivar, the optimum ethephon application rate ranged from 100 to 300 mg.liter ${ }^{-1}$ after color initiation (veraison) (Chakrawar and Rane, 1977; Jensen et al., 1980; Weaver and Pool, 1971). Jensen et al. (1980) concluded that all red varieties tested had increased color with ethephon whether exposed to light or not. The reported effects of ethephon on berry chemistry are contradictory. Some studies showed increases in percent soluble solids (Agaolu, 1981; Jensen et al., 1980; Singh and Chundawat, 1978) and others indicated increases in the percent soluble solids : acid ratio ascribed mainly to decreases in TA (El-Banna and Weaver, 1979; Weaver and Montgomery, 1974; Weaver and Pool, 1971). Several researchers 
reported no changes in either characteristic (Clore and Fay, 1970; Lavee, 1981; Patterson and Zoecklein, 1990). We chose our ethephon application rate and timing based on previous research with 'Reliance' in Ohio (G.A. Cahoon, personal communication). The main objective of this study was to determine if canopy management (cluster thinning, shoot positioning, and leaf removal) improved 'Reliance' coloration . Total yield, berry weight, percent soluble solids, $\mathrm{pH}$, and TA were measured to assess the effect of the treatments on berry quality and quantity.

\section{Materials and Methods}

The experiment was conducted during 1989 and 1990 at the Nooncaster Vineyard in Fayetteville, Ark., on vines planted in 1985. The vines were spur-pruned and trained to a single-curtain, bilateral cordon trellis system. Each arm had six to seven spurs with three buds per spur ( $\approx 36$ buds per vine).

There were eight treatments with four replications; each replication consisted of five vines. The same vines were used in both years. Grape clusters were exposed to two levels of leaf removal and shoot positioning ( $\mathrm{L}=$ leaf removal, direct exposure to light with leaves removed to the first node beyond the terminal cluster and shoots positioned, $\mathrm{NL}=$ indirect exposure with no leaves removed and no shoot positioning), two levels of preharvest ethephon spray $(\mathrm{E}=$ sprayed 2 weeks after veraison, $\mathrm{NE}=$ no ethephon), and either thinned to a basal cluster (T) or nonthinned (NT) (Table 1). Control vines were untreated.

Depending on treatment, grape vines were subjected to the following chronology of events. In May, treatments 2, 4, 6, and 7 were thinned to a single basal cluster (Table 1). In June, treatments $3,4,5$, and 6 were shoot-positioned by placing horizontally growing shoots in a vertically downward position. In addition, leaves were removed to the first node beyond the terminal cluster on each shoot 2 weeks before veraison. In July, 2 weeks after veraison, treatments $1,5,6$, and 7 were treated with ethephon at a concentration of $100 \mathrm{mg} \cdot$ liter $^{-1}$ until runoff $(\approx 1$ liter/vine $)$. Preliminary experiments showed that ethephon rates $>100 \mathrm{mg} \cdot \mathrm{liter}^{-1}$ accelerated berry abscission and shattering.

A datalogger (Omnidata International, Logan, Utah) with light and temperature sensors was placed in the vineyard 4 weeks before harvest. Photosynthetic photon flux (PPF) was measured hourly near exposed and nonexposed clusters using two quantum light sensors for each situation $\left(\mu \mathrm{mol} \cdot \mathrm{m}^{-2} \cdot \mathrm{s}^{-1}\right)$. Thermocouple probes were inserted into berries in the midsection of five exposed and five nonexposed clusters, and hourly temperatures were recorded.

At harvest, two 100-berry samples were taken from the midsection of randomly selected clusters from each treatment. One set of samples was weighed. Berry skin color was analyzed with a colorimeter. The second set of samples was stored in a freezer at -20C. Samples were allowed to thaw overnight and blended for 15 sec. A sample of the raw juice and pulp was allowed to reach room temperature (20C), and percent soluble solids was read using a digital refractometer. All other parameters were determined on juice that had been cooked for an hour in a water bath at $85 \mathrm{C}$, cooled for $20 \mathrm{~min}$ in a $2 \mathrm{C}$ cold room, and then squeezed through cheesecloth to obtain $150 \mathrm{ml}$. The "L", "a", and "b" values were recorded using a color difference meter with the standards, dark red plate $(\mathrm{L}=23.1, \mathrm{a}=22.0, \mathrm{~b}=7.1)$, and white plate $(\mathrm{L}=92.4$, a $=-1, \mathrm{~b}=1.0)$. The $\mathrm{pH}$ was also determined on all samples using an ion analyzer. TA was determined by a titration with $0.1 \mathrm{~N} \mathrm{NaOH}$ on a 5-ml sample diluted to $126 \mathrm{ml}$ with deionized water to an 8.2 endpoint. The skin color of individual berries was compared to a standard (no. D33 C-1524, $\mathrm{L}=25.5, \mathrm{a}=27.5$, and $\mathrm{b}=12.3$ ), and results were interpreted according to the Gardner color analysis system. "L" indicates lightness or darkness (e.g., 100 = white and 0 = black). Positive "a" values indicate redness and negative "a" values indicate greenness. Positive " $b$ " values measure yellowness and negative values measure blueness.

The design was a completely randomized $2 \times 2 \times 2$ factorial with presence or absence of leaf removal and shoot positioning, presence or absence of preharvest ethephon spray, and presence or absence of thinning as the three factors analyzed by SAS's GLM procedure (SAS Institute, 1985). Independence of observations over years is an unverified assumption. An LSD at $P=0.05$ was used to separate means, where appropriate.

\section{Results and Discussion}

In 1989, clusters exposed to the sun had a maximum average daily temperature 4.3C above that for nonexposed clusters, with an average difference of 1.4C. In 1990, the maximum difference was $2.4 \mathrm{C}$ and the average difference was $1.5 \mathrm{C}$. In 1989, the average daily maximum temperature was $35.8 \mathrm{C}$ for exposed clusters and 29.4C for nonexposed clusters. In 1990, the average maximum temperature was 33.4C for exposed clusters and $30 \mathrm{C}$ for nonexposed clusters. In 1989 , the average PPF was $306.0 \mu \mathrm{mol} \cdot \mathrm{m}^{-2} \cdot \mathrm{s}^{-1}$ for exposed clusters and $9.9 \mu \mathrm{mol} \cdot \mathrm{m}^{-2} \cdot \mathrm{s}^{-1}$ for nonexposed clusters. In 1990 , the average PPF was $359.0 \mu \mathrm{mol} \cdot \mathrm{m}^{-2} \cdot \mathrm{s}^{-1}$ for exposed clusters and $10.1 \mu \mathrm{mol} \cdot \mathrm{m}^{-2} \cdot \mathrm{s}^{-1}$ for nonexposed clusters.

Thinned treatments matured 5 to 8 days earlier than nonthinned treatments in 1989 and 5 to 7 days earlier in 1990 (Table 1). Thinned ethephon treatments matured 2 days earlier in 1989 and 3 days earlier in 1990 than thinned nonethephon treatments. A partial reason for the earlier harvest dates in 1990 was an overall lighter crop load than in 1989 (Table 2).

Yield was lowered by cluster thinning in 1989 and 1990 (Table 2). The lower yields in 1990 compared to 1989 may be attributed to minimum temperatures of $-23,-24$, and $-22 \mathrm{C}$ on 22,23 , and 24 Dec. 1989. There were no two- or three-way interactions for the parameters total yield, volume, and weight.

In 1989, berry weight was greater for thinned treatments (Table 2). This did not occur in 1990 because yield was very low in both treatments. The average difference in yield between thinned and nonthinned treatments was $\approx 20 \mathrm{~kg}$ in 1989 and $6 \mathrm{~kg}$ in 1990 . Leaf removal and ethephon did not affect berry weight. These results contradict several studies that report that defoliation reduced berry size (Buttrose, 1966; Kliewer, 1970; Kliewer and Antliff, 1970).

Table 1. Harvest dates of 'Reliance' treatments for trials conducted during 1989 and 1990 growing seasons. $^{\mathrm{Z}}$

\begin{tabular}{lcc}
\hline \hline Treatment $^{\mathrm{y}}$ & 1989 & 1990 \\
\hline 1$) \mathrm{NL} \times \mathrm{E} \times \mathrm{NT}$ & 12 Aug. & 4 Aug. \\
2) $\mathrm{NL} \times \mathrm{NE} \times \mathrm{T}$ & 9 Aug. & 2 Aug. \\
3) $\mathrm{L} \times \mathrm{NE} \times \mathrm{NT}$ & 15 Aug. & 6 Aug. \\
4) $\mathrm{L} \times \mathrm{NE} \times \mathrm{T}$ & 9 Aug. & 2 Aug. \\
5) $\mathrm{L} \times \mathrm{E} \times \mathrm{NT}$ & 12 Aug. & 4 Aug. \\
6) $\mathrm{L} \times \mathrm{E} \times \mathrm{T}$ & 7 Aug. & $31 \mathrm{July}$ \\
7) $\mathrm{NL} \times \mathrm{E} \times \mathrm{T}$ & $7 \mathrm{Aug}$. & $31 \mathrm{July}$ \\
8) $\mathrm{NL} \times \mathrm{NE} \times \mathrm{NT}$ & 15 Aug. & 6 Aug.
\end{tabular}

${ }^{\mathrm{z} N o o n c a s t e r}$ Vineyard, Fayetteville, Ark. Treatments harvested when juice from a random sample of 20 berries reached $20 \%$ soluble solids as determined by a hand-held refractometer.

${ }^{y} \mathrm{~L}=$ vines shoot-positioned, leaves removed to first node beyond the terminal cluster; $\mathrm{E}=$ foliage treated with ethephon at $100 \mathrm{mg} \cdot \mathrm{liter}^{-1} 2$ weeks after veraison, sprayed until runoff; $\mathrm{T}=$ shoots thinned to a single basal cluster; $\mathrm{N}=$ no treatment. 
However, they are consistent with the results of Kliewer and Bledsoe (1987), which showed that the timing and severity of basal leaf removal did not affect berry weight. Kliewer and Bledsoe (1987) hypothesized that removing basal leaves may not affect

Table 2. Yield response of 'Reliance' grapes to canopy management and ethephon, final harvest.

\begin{tabular}{|c|c|c|c|c|}
\hline \multirow[b]{2}{*}{ Variable $^{\mathrm{x}}$} & \multicolumn{2}{|c|}{$\begin{array}{l}\text { Yield/five } \\
\text { vines }^{\mathrm{z}}(\mathrm{kg})\end{array}$} & \multicolumn{2}{|c|}{$\begin{array}{c}\text { Wt/berry }{ }^{y} \\
(\mathrm{~g})\end{array}$} \\
\hline & 1989 & 1990 & 1989 & 1990 \\
\hline \multicolumn{5}{|l|}{ Leaf removal } \\
\hline $\mathrm{L}$ & 58.0 & 23.6 & 1.8 & 2.0 \\
\hline $\mathrm{NL}$ & 54.7 & 21.1 & 1.8 & 2.0 \\
\hline \multicolumn{5}{|l|}{ Ethephon } \\
\hline $\mathrm{E}$ & 58.6 & 22.7 & 1.8 & 2.0 \\
\hline $\mathrm{NE}$ & 54.1 & 22.1 & 1.8 & 2.0 \\
\hline \multicolumn{5}{|l|}{ Thinning } \\
\hline $\mathrm{T}$ & $46.1 \mathrm{~b}$ & $19.1 \mathrm{~b}$ & $1.9 \mathrm{a}$ & 2.0 \\
\hline NT & $66.6 \mathrm{a}$ & $25.7 \mathrm{a}$ & $1.7 \mathrm{~b}$ & 1.9 \\
\hline \multicolumn{5}{|c|}{ F significance } \\
\hline $\mathrm{L}$ & NS & NS & NS & NS \\
\hline $\mathrm{E}$ & NS & NS & NS & NS \\
\hline $\mathrm{E} \times \mathrm{L}$ & NS & NS & NS & NS \\
\hline $\mathrm{T}$ & $*$ & $*$ & $*$ & $*$ \\
\hline $\mathrm{T} \times \mathrm{L}$ & NS & NS & NS & NS \\
\hline $\mathrm{T} \times \mathrm{E}$ & NS & NS & NS & NS \\
\hline $\mathrm{T} \times \mathrm{E} \times \mathrm{L}$ & NS & NS & NS & NS \\
\hline
\end{tabular}

${ }^{\mathrm{z}}$ Values are means of 16 replications, 5 vines.

y Values are means of 16 replications, 5 vines, 100-berry sample.

${ }^{\mathrm{x}} \mathrm{L}=$ vines shoot positioned, leaves removed to first node beyond the terminal cluster; $\mathrm{E}=$ foliage treated with ethephon at $100 \mathrm{mg} \cdot \mathrm{liter}^{-1} 2$ weeks after veraison, sprayed until runoff; $\mathrm{T}=$ shoots thinned to a single basal cluster; $\mathrm{N}=$ no treatment.

Ns, ${ }^{*}$ Nonsignificant or significant at $P \leq 0.05$, respectively. yield because these leaves are not as photosynthetically active and, therefore, do not significantly contribute to the carbohydrate status of the plant during maturation. They cited previous research by Kreidemann et al. (1969), which showed that recently matured, fully expanded grape leaves had a photosynthetic rate about onethird higher than older basal leaves.

In 1990, leaf removal with shoot positioning, ethephon, and thinning resulted in lighter colored skin (higher "L" value) (Table $3)$. In 1989, regardless of ethephon, leaf removal resulted in increased " $\mathrm{L}$ " values for thinned $(\mathrm{L} \times \mathrm{T}, 29.0)$ and nonthinned $(\mathrm{L}$ $\times \mathrm{NT}, 28.5)$ treatments, illustrating lighter colored skin compared to $\mathrm{NL} \times \mathrm{T}(27.5)$ and NL $\times$ NT (25.2). In 1989, ethephon did not affect the "L" values of thinned $(\mathrm{E} \times \mathrm{T}, 28.6)$ or nonthinned $(\mathrm{E} \times$ NT, 28.7) treatments; however, in the absence of ethephon, the thinned treatment $(\mathrm{NE} \times \mathrm{T}, 27.9)$ had a higher " $\mathrm{L}$ " value than the nonthinned treatment $(\mathrm{NE} \times \mathrm{NT}, 25.0)$, which had the lowest " $\mathrm{L}$ " value of all treatments.

Leaf removal in 1989 and 1990 and thinning in 1989 resulted in larger "a" values, indicating redder skin (Table 3 ). When ethephon was applied in 1990, thinning $(\mathrm{E} \times \mathrm{T}, 10.6)$ resulted in greater " $\mathrm{a}$ " values than nonthinning $(\mathrm{E} \times \mathrm{NT}, 10.2)$ (Table 3$)$. When no ethephon was applied, thinning $(\mathrm{NE} \times \mathrm{T}, 9.7)$ resulted in smaller "a" values than nonthinning $(\mathrm{NE} \times \mathrm{NT}, 10.4)$.

In 1990, leaf removal increased "b" values (Table 3). In 1989, the $\mathrm{NL} \times \mathrm{T}(2.6)$ and NL $\times \mathrm{NT}$ (2.8) treatments had lower " $b$ " values than the $\mathrm{L} \times \mathrm{NT}(5.4)$ and $\mathrm{L} \times \mathrm{T}$ (3.7) treatments. Leaf removal treatments $(\mathrm{L} \times \mathrm{NT}$ and $\mathrm{L} \times \mathrm{T})$ were more yellow than control treatments $(\mathrm{NL} \times \mathrm{NT}$ and $\mathrm{NL} \times \mathrm{T})$. However, the leaf removal and nonthinned treatments $(\mathrm{L} \times \mathrm{NT})$ had greater " $b$ " values than the thinned treatments $(\mathrm{L} \times \mathrm{T})$, a result indicating that the berry skin was more yellow than in thinned treatments. In 1990, the $\mathrm{E} \times \mathrm{T}$ treatment (2.2) had the greatest " $b$ " value of all other treatments, and the nonthinned treatments $(\mathrm{E} \times \mathrm{NT}, 0.9 ; \mathrm{NE} \times \mathrm{NT}, 1.2)$ had lower " $b$ " values than all other treatments.

These results partially support many studies that ethephon

Table 3. Skin color response of 'Reliance' grapes to canopy manipulation and ethephon, final harvest, 1989 and 1990.

\begin{tabular}{|c|c|c|c|c|c|c|}
\hline \multirow[b]{3}{*}{ Variable $^{\mathrm{y}}$} & \multicolumn{6}{|c|}{ Skin color ${ }^{2}$} \\
\hline & \multicolumn{2}{|c|}{ "L" } & \multicolumn{2}{|c|}{ "a" } & \multicolumn{2}{|c|}{ "b" } \\
\hline & 1989 & 1990 & 1989 & 1990 & 1989 & 1990 \\
\hline \multicolumn{7}{|l|}{ Leaf removal } \\
\hline $\mathrm{L}$ & 28.7 & $27.0 \mathrm{a}$ & $4.2 \mathrm{a}$ & $10.5 \mathrm{a}$ & 4.6 & $2.1 \mathrm{a}$ \\
\hline NL & 26.3 & $25.7 \mathrm{~b}$ & $2.8 \mathrm{~b}$ & $9.9 \mathrm{~b}$ & 2.7 & $0.8 \mathrm{~b}$ \\
\hline \multicolumn{7}{|l|}{ Ethephon } \\
\hline $\mathrm{E}$ & 28.6 & $26.8 \mathrm{a}$ & 3.6 & $10.4 \mathrm{a}$ & 3.7 & 1.6 \\
\hline $\mathrm{NE}$ & 26.4 & $25.9 \mathrm{~b}$ & 3.4 & $10.1 \mathrm{~b}$ & 3.6 & 1.4 \\
\hline \multicolumn{7}{|l|}{ Thinning } \\
\hline $\mathrm{T}$ & 28.2 & $27.1 \mathrm{a}$ & $4.0 \mathrm{a}$ & 10.3 & 4.1 & 1.9 \\
\hline NT & 26.8 & $25.7 \mathrm{~b}$ & $3.1 \mathrm{~b}$ & 10.1 & 3.2 & 1.0 \\
\hline \multicolumn{7}{|c|}{ F significance } \\
\hline $\mathrm{L}$ & NS & $*$ & $*$ & $*$ & NS & $*$ \\
\hline $\mathrm{E}$ & NS & $*$ & NS & $*$ & NS & NS \\
\hline $\mathrm{E} \times \mathrm{L}$ & NS & NS & NS & NS & NS & NS \\
\hline $\mathrm{T}$ & NS & $*$ & $*$ & NS & NS & NS \\
\hline $\mathrm{T} \times \mathrm{L}$ & $*$ & NS & NS & NS & $*$ & NS \\
\hline $\mathrm{T} \times \mathrm{E}$ & $*$ & NS & NS & $*$ & NS & $*$ \\
\hline $\mathrm{T} \times \mathrm{E} \times \mathrm{L}$ & NS & NS & NS & NS & NS & NS \\
\hline
\end{tabular}

${ }^{\mathrm{z}}$ Values are means of 16 replications, 100-berry sample.

${ }^{\mathrm{y}} \mathrm{L}=$ vines shoot positioned, leaves removed to first node beyond the terminal cluster; $\mathrm{E}=$ foliage treated with ethephon at $100 \mathrm{mg}$.

liter $^{-1} 2$ weeks after veraison, sprayed until runoff; $\mathrm{T}=$ shoots thinned to a single basal cluster; $\mathrm{N}=$ no treatment.

Ns, ${ }^{*}$ Nonsignificant or significant at $P \leq 0.05$, respectively. 
alters coloration of several grape cultivars (Chakrawar and Rane, 1977; Clore and Fay, 1970; Weaver and Pool, 1971). In 1990, thinning and ethephon interaction resulted in fruit with increased "a" and "b" values. Ethephon did not independently affect the redness of skin color in either year.

Juice color reflects the anthocyanin content of the grape berry. Leaf removal in 1990 increased "L" value (lighter color) (Table 4). In 1989, there was a significant three-way interaction for " $L$ " values among treatments. When ethephon was applied in 1989, leaf removal and thinning $(\mathrm{L} \times \mathrm{E} \times \mathrm{T}, 34.6)$ decreased " $\mathrm{L}$ " over all other leaf removal and thinning combinations $(\mathrm{L} \times \mathrm{E} \times \mathrm{NT}, 35.3$; $\mathrm{NL} \times \mathrm{E} \times \mathrm{T}, 35.2 ; \mathrm{NL} \times \mathrm{E} \times \mathrm{NT}, 35.2)$, which were not different from each other. When ethephon was not applied, there were no significant differences among "L" values for all leaf removal and thinning combinations $(\mathrm{L} \times \mathrm{NE} \times \mathrm{T}, 34.7$; $\mathrm{L} \times \mathrm{NE} \times \mathrm{NT}, 34.8 ; \mathrm{NL}$ $\times \mathrm{NE} \times \mathrm{T}, 34.8 ; \mathrm{NL} \times \mathrm{NE} \times \mathrm{NT}, 35.1)$.

Ethephon decreased "a" values in 1989, and leaf removal increased "a" values in 1990 (Table 4). An increase in "a" values signifies redder juice. Leaf removal in both years increased the "b" value, indicating a more yellow color. Juice from leaf removal treatments had increased " $a$ " and " $b$ " values. The resulting color was orange. A possible explanation for the color difference among leaf removal and nonleaf-removal treatments was the increased temperature of berries directly exposed to light as a result of leaf removal and shoot positioning. Day temperatures of 32.7 to $35 \mathrm{C}$ and differences of $>10 \mathrm{C}$ between day and night temperatures inhibited anthocyanin formation (Kliewer and Lider, 1970; Kliewer and Torres, 1972).

Treatments did not consistently affect juice percent soluble solids, pH, and TA (Table 5). In 1989, there was a two-way interaction between leaf removal and thinning for the percent soluble solids of raw juice (Table 5). The $\mathrm{L} \times \mathrm{T}$ (20.7) treatment had higher percent soluble solids values than all other treatment combinations $(\mathrm{L} \times \mathrm{NT}, 19.5 ; \mathrm{NL} \times \mathrm{NT}, 19.6 ; \mathrm{NL} \times \mathrm{T}, 19.7) . \mathrm{In}$ 1990 , there was a three-way interaction among leaf removal, thinned, and ethephon treatments for the percent soluble solids of raw juice (Table 5). When ethephon was applied and vine clusters were thinned, leaf removal did not affect percent soluble solids. $\mathrm{L}$ $\times \mathrm{E} \times \mathrm{T}(21.6)$ and $\mathrm{NL} \times \mathrm{E} \times \mathrm{T}$ (21.7) values did not differ. When ethephon was applied to nonthinned vines, however, the leaf removal treatments $(\mathrm{L} \times \mathrm{E} \times \mathrm{NT}, 21.7)$ had higher percent soluble solids values than the nonleaf-removal treatments $(\mathrm{NL} \times \mathrm{E} \times \mathrm{NT}$, 20.9). When ethephon was not applied but vines were clusterthinned, leaf removal $(\mathrm{L} \times \mathrm{NE} \times \mathrm{T}, 22.1)$ increased percent soluble solids. Nonethephon treatments $(\mathrm{L} \times \mathrm{T} \times \mathrm{NE}, 22.1 ; \mathrm{L} \times \mathrm{NT} \times \mathrm{NE}$, 22.3; NL $\times \mathrm{NE} \times \mathrm{NT}, 22.6$ ) had higher percent soluble solids values than ethephon treatments.

These results suggest that leaf removal and interactions between leaf removal and thinning may produce berries with higher percent soluble solids and ethephon may produce berries with lower percent soluble solids. Previous research showing that fruit grown under low light conditions have lower percent soluble solids or that shading reduces the percent soluble solids (Jensen et al., 1976; Kliewer et al., 1967; Smart 1982) is consistent with these conclusions. Unlike previous studies showing that ethephon increased or had no effect on percent soluble solids, this study suggests that ethephon decreases percent soluble solids in 'Reliance'. Jensen et al. (1980) found that, with ethephon, clusters may color at $12 \%$ to $15 \%$ soluble solids, while normally they would not color before $15 \%$ soluble solids. Kliewer and Bledsoe (1987) showed that removing basal leaves increased overall percent soluble solids. Cluster-thinned vines had berries with higher percent soluble solids (Kliewer and Weaver, 1971).

In 1989, there were no significant changes in $\mathrm{pH}$ among the treatments. In 1990, leaf removal treatments had lower $\mathrm{pH}$ values (Table 7). There was a two-way interaction between ethephon and thinning in 1990 (Table 5). The nonthinned treatments $(\mathrm{E} \times \mathrm{NT}$, 3.37; $\mathrm{NE} \times \mathrm{NT}, 3.34$ ) had significantly higher $\mathrm{pH}$ values than thinned treatments $(\mathrm{NE} \times \mathrm{T}, 3.32 ; \mathrm{E} \times \mathrm{T}, 3.27)$. In 1989 and 1990, leaf removal decreased TA and ethephon application increased TA

Table 4. Juice color response of 'Reliance' grapes to canopy management and ethephon, final harvest, 1989 and 1990.

\begin{tabular}{|c|c|c|c|c|c|c|}
\hline \multirow[b]{3}{*}{ Variable $^{\mathrm{y}}$} & \multicolumn{6}{|c|}{ Juice color $^{2}$} \\
\hline & \multicolumn{2}{|c|}{ "L" } & \multicolumn{2}{|c|}{ "a" } & \multicolumn{2}{|c|}{ "b" } \\
\hline & 1989 & 1990 & 1989 & 1990 & 1989 & 1990 \\
\hline \multicolumn{7}{|l|}{ Leaf removal } \\
\hline $\mathrm{L}$ & 35.1 & $33.8 \mathrm{a}$ & 2.8 & $4.5 \mathrm{a}$ & $4.1 \mathrm{a}$ & $3.4 \mathrm{a}$ \\
\hline NL & 34.9 & $33.3 \mathrm{~b}$ & 2.9 & $4.0 \mathrm{~b}$ & $2.9 \mathrm{~b}$ & $3.1 \mathrm{~b}$ \\
\hline \multicolumn{7}{|l|}{ Ethephon } \\
\hline $\mathrm{E}$ & 35.1 & 33.6 & $2.7 \mathrm{~b}$ & 4.3 & 3.6 & 3.3 \\
\hline $\mathrm{NE}$ & 34.9 & 33.6 & $3.1 \mathrm{a}$ & 4.3 & 3.4 & 3.2 \\
\hline \multicolumn{7}{|l|}{ Thinning } \\
\hline $\mathrm{T}$ & 34.8 & 33.6 & 3.0 & 4.5 & 3.6 & 3.3 \\
\hline NT & 35.1 & 33.5 & 2.7 & 4.1 & 3.4 & 3.2 \\
\hline \multicolumn{7}{|l|}{ F significance } \\
\hline $\mathrm{L}$ & NS & $*$ & NS & $*$ & $*$ & $*$ \\
\hline $\mathrm{E}$ & NS & NS & $*$ & NS & NS & NS \\
\hline $\mathrm{E} \times \mathrm{L}$ & NS & NS & NS & NS & NS & NS \\
\hline $\mathrm{T}$ & NS & NS & NS & NS & NS & NS \\
\hline $\mathrm{T} \times \mathrm{L}$ & NS & NS & NS & NS & NS & NS \\
\hline $\mathrm{T} \times \mathrm{E}$ & NS & NS & NS & NS & NS & NS \\
\hline $\mathrm{T} \times \mathrm{E} \times \mathrm{L}$ & $*$ & NS & NS & NS & NS & NS \\
\hline
\end{tabular}

${ }^{\mathrm{z}}$ Values are means of 16 replications, 100-berry sample.

${ }^{\mathrm{y}} \mathrm{L}=$ vines shoot positioned, leaves removed to first node beyond the terminal cluster; $\mathrm{E}=$ foliage treated with ethephon at $100 \mathrm{mg}$.

liter $^{-1} 2$ weeks after veraison, sprayed until runoff; $\mathrm{T}=$ shoots thinned to a single basal cluster; $\mathrm{N}=$ no treatment.

Ns, ${ }^{*}$ Nonsignificant or significant at $P \leq 0.05$, respectively. 
Table 5. Berry juice chemistry response of 'Reliance' grapes to canopy manipulation and ethephon, final harvest, 1989 and 1990.

\begin{tabular}{|c|c|c|c|c|c|c|}
\hline \multirow[b]{3}{*}{ Variable $^{\mathrm{x}}$} & \multicolumn{6}{|c|}{ Berry chemistry $^{z}$} \\
\hline & \multicolumn{2}{|c|}{ Soluble solids (\%) } & \multicolumn{2}{|c|}{$\mathrm{pH}$} & \multicolumn{2}{|c|}{$\mathrm{TA}^{\mathrm{y}}$} \\
\hline & 1989 & 1990 & 1989 & 1990 & 1989 & 1990 \\
\hline \multicolumn{7}{|l|}{ Leaf removal } \\
\hline $\mathrm{L}$ & 20.1 & 21.9 & 3.47 & $3.29 \mathrm{~b}$ & $0.65 \mathrm{~b}$ & $0.83 \mathrm{~b}$ \\
\hline NL & 19.6 & 21.5 & 3.33 & $3.35 \mathrm{~b}$ & $0.70 \mathrm{a}$ & $0.94 \mathrm{a}$ \\
\hline \multicolumn{7}{|l|}{ Ethephon } \\
\hline $\mathrm{E}$ & 19.7 & 21.5 & 3.47 & 3.31 & $0.70 \mathrm{a}$ & $0.92 \mathrm{a}$ \\
\hline $\mathrm{NE}$ & 20.0 & 22.0 & 3.33 & 3.33 & $0.65 \mathrm{~b}$ & $0.85 \mathrm{~b}$ \\
\hline \multicolumn{7}{|l|}{ Thinning } \\
\hline $\mathrm{T}$ & 20.2 & 21.6 & 3.33 & 3.30 & $0.69 \mathrm{a}$ & 0.90 \\
\hline NT & 19.5 & 21.9 & 3.48 & 3.35 & $0.66 \mathrm{~b}$ & 0.87 \\
\hline \multicolumn{7}{|c|}{ F significance } \\
\hline $\mathrm{L}$ & NS & NS & NS & $*$ & $*$ & $*$ \\
\hline $\mathrm{E}$ & NS & NS & NS & NS & $*$ & $*$ \\
\hline $\mathrm{E} \times \mathrm{L}$ & NS & NS & NS & NS & NS & NS \\
\hline $\mathrm{T}$ & NS & NS & NS & NS & $*$ & NS \\
\hline $\mathrm{T} \times \mathrm{L}$ & $*$ & NS & NS & NS & NS & NS \\
\hline $\mathrm{T} \times \mathrm{E}$ & NS & NS & NS & $*$ & NS & NS \\
\hline $\mathrm{T} \times \mathrm{E} \times \mathrm{L}$ & NS & $*$ & NS & NS & NS & NS \\
\hline
\end{tabular}

${ }^{\mathrm{z}}$ Values are means of 100-berry samples, 16 replications.

y $\mathrm{TA}=$ titratable acidity [tartaric acid $(\mathrm{g} / 100 \mathrm{ml})] ; \mathrm{ml} 0.1 \mathrm{~N} \mathrm{NaOH}$ required to change the $\mathrm{pH}$ of a 5 -ml sample diluted to $126 \mathrm{ml}$ with deionized water to an 8.2 endpoint.

${ }^{\mathrm{x}} \mathrm{L}=$ vines shoot positioned, leaves removed to first node beyond the terminal cluster; $\mathrm{E}=$ foliage treated with ethephon at 100 $\mathrm{mg} \cdot$ liter $^{-1} 2$ weeks after veraison, sprayed until runoff; $\mathrm{T}=$ shoots thinned to a single basal cluster; $\mathrm{N}=$ no treatment;

Ns, ${ }^{*}$ Nonsignificant or significant at $P \leq 0.05$, respectively.

(Table 5). In 1989, nonthinned treatments had significantly lower TA values than thinned treatments.

Studies have shown that ethephon increases pH (J.R. Morris, personal communication) and decreases TA (El-Banna and Weaver, 1979; Weaver and Montgomery, 1974; Weaver and Pool, 1971). In this study, however, ethephon resulted in higher TA values in both years. Fruit grown under low light have lower $\mathrm{pH}$ and higher TA (Kliewer et al., 1967). The effect of light on 'Reliance' that we observed is consistent with a Kliewer and Bledsoe (1987) study showing that leaf removal decreased TA and $\mathrm{pH}$.

The main objective of this study was to determine if grape skin color could be improved by canopy management and/or ethephon. Thinning reduced overall yields but resulted in increased berry weight in 1 year. Attempts to improve skin color were inconclusive; however, thinning, whether due to freezing primary buds or actual cluster thinning, resulted in more evenly colored, redder fruit among all treatments. Leaf removal that directly exposed the clusters to sunlight caused an undesirable lightening and yellowing of skin color in both years. Ethephon cannot be recommended at this time because the results were not consistent for the 2-year period. Treatments had a minimal effect on berry chemistry parameters.

\section{Literature Cited}

Agaolu, Y.S. 1981. Effects of various application methods of Ethrel on some quality characteristics of grapes. Amer. J. Enol. Viticult. 32:151153.

Buttrose, M.S. 1966. The effect of reducing leaf area on the growth of roots, stems and berries of Gordo grapevines. Vitis 5:455-464.

Buttrose, M.S., C.R. Hale, and W.M. Kliewer. 1971. Effect of temperature on the composition of 'Cabernet Sauvignon' berries. Amer. J. Enol. Viticult. 22:71-75.

Chakrawar, V.R. and D.A. Rane. 1977. Effect of Ethrel (2chloroethylphosphonic acid) on uneven ripening and berry characteris- tics of Gulabi and Banglore purple grapes. Vitis 16:97-99.

Clark, J.R., G.E. Fernandez, and D.G. Dombek. 1989. Flower cluster thinning of 'Mars' and 'Venus' grapes. Arkansas Farm Res. 38:11.

Clore, W.J. and R.D. Fay. 1970. The effect of pre-harvest application of Ethrel on Concord grapes. HortScience 5:21-3.

Coombe, B.G. 1987. Influence of temperature on composition and quality of grapes. Acta Hort. 206:23-25.

Degner, R.L. and G.F. Fairchild. 1987. Marketing strategies for Floridagrown table grapes. Proc. Florida State Hort. Soc. 100:405-408.

El-Banna, G.I. and R.J. Weaver. 1979. Effect of ethephon and gibberellin on maturation of ungirdled Thompson Seedless grapes. Amer. J. Enol. Viticult. 30:11-13.

English, J.T., A.M. Bledsoe, J.J. Marois, and W.M. Kliewer. 1990. Influence of grapevine canopy management on evaporative potential in the fruit zone. Amer. J. Enol. Viticult. 41:137-141.

Jensen, F., J. Kissler, W. Peacock, G. Leavitt, H. Andris, D. Luvisi. 1980. Color and maturity promotion in table grapes with ethephon. Proc. Symp. Grape and Wine Centennial, Univ. of California, Davis. p. 118131.

Kliewer, W.M. 1970. Effect of time and severity of defoliation on growth and composition of 'Thompson Seedless' grapes. Amer. J. Enol. Viticult. 21:237-250.

Kliewer, W.M. and A.J. Antliff. 1970. Influence of defoliation, leaf darkening, and cluster shading on the growth and composition of 'Sultana' grapes. Amer. J. Enol. Viticult. 21:26-36.

Kliewer, W.M. and A. Bledsoe. 1987. Influence of hedging and leaf removal on canopy microclimate, grape composition and wine quality under California conditions. Acta Hort. 206:157-168.

Kliewer, W.M. and L.A. Lider. 1970. Effect of day temperature and light intensity on growth and composition of Vitis vinifera L. fruits. J. Amer. Soc. Hort. Sci. 95:766-769.

Kliewer, W.M., L.A. Lider, and H.B. Schultz. 1967. Influence of artificial shading of vineyards on the concentration of sugar and organic acids in grapes. Amer. J. Enol. Viticult. 18:78-86.

Kliewer, W.M. and R.E. Torres. 1972. Effect of controlled day and night temperatures on grape coloration. Amer. J. Enol. Viticult. 23:71-77.

Kliewer, W.M. and R.J. Weaver. 1971. Effect of crop level and leaf area 
on growth, composition, and coloration of ‘Tokay' grape. Amer. J. Enol. Viticult. 22:172-177.

Koblet, W. 1987. Effectiveness of shoot topping and leaf removal as a means of improving quality. Acta Hort. 206:141-155.

Kreidemann, P.E., W.M. Kliewer, and J.M. Harris. 1969. Leaf age and photosynthesis in Vitis vinifera L. Vitis 9:97-104.

Lavee, S. 1981. Control of grapevine growth and development, using ethylene releasing substances and some aspects of their action. Amer. J. Enol. Viticult. 32:126-131.

May, P., N.J. Shaulis, and A.J. Antliff. 1969. The effect of controlled defoliation in the Sultana vine. Amer. J. Enol. Viticult. 20:237-250.

Moore, J.N. 1983. 'Reliance' seedless grape. HortScience 18:963.

Morrison, J.C. and A.C. Noble. 1990. The effects of leaf and cluster shading on the composition of Cabernet Sauvignon grapes and on fruit and wine sensory properties. Amer. J. Enol. Viticult. 41:193-200.

Patterson, W.K. and B.W. Zoecklein. 1990. Vegetative and berry chemistry response to canopy manipulation and ethephon in 'Norton' grapes. HortScience 25:905-908.

Radler, F. 1965. The effect of temperature on the ripening of Sultana grapes. Amer. J. Enol. Viticult. 16:38-41.

Rojas-Lara, B.A. and J.C. Morrison. 1989. Differential effects of shading fruit or foliage on the development and composition of grape berries. Vitis 28:199-208.
SAS Institute. 1985. SAS user's guide: Basics. version 5. SAS Inst., Cary, N.C. Singh, I.S. and B.S. Chundawat. 1978. Effect of ethephon in ripening of 'Delight' grapes. HortScience 13:251.

Smart, R.E. 1982. Vine manipulation to improve wine grape quality. Symp. Proc. Grape and Wine Centennial, Univ. of California, Davis, 1980. p. 362-375.

Smart, R.E. 1985. Principles of grapevine canopy microclimate manipulation with implications for yield and quality. A review. Amer. J. Enol. Viticult. 36:230-239.

Smart, R.E. and T.R. Sinclair. 1976. Solar heating of grape berries and other spherical fruits. Agr. Meteorol. 17:241-259.

Smart, R.E., S.M. Smith, and R.V. Winchester. 1988. Light quality and quantity effects on fruit ripening for Cabernet Sauvignon. Amer. J. Enol. Viticult. 39:109-116.

Weaver, R.J. and R. Montgomery. 1974. Effect of ethephon on coloration and maturation of wine grapes. Amer. J. Enol. Viticult. 25:39-41.

Weaver, R.J. and R.M. Pool. 1971. Effect of 2-chloroethyl phosphonic acid (ethephon) on maturation of Vitis vinifera L. J. Amer. Soc. Hort. Sci. 96:725-727.

Wicks, A.S., W.M. Kliewer, and F. Jensen. 1982. Influence of light and ethephon on formation of anthocyanins in several table grapes. Symp. Proc. Grape and Wine Centennial, Univ. of California, Davis, 1980. p. $148-150$. 